\title{
El uso de cinturón de seguridad también prevendría la muerte de los otros ocupantes del vehículo
}

\section{Objetivo}

Estimar la asociación entre la muerte de un ocupante del automóvil y el uso de medidas de seguridad por otros ocupantes del mismo automóvil.

\section{Diseño}

Estudio de cohorte retrospectiva pareado que compara el resultado (muerte o nó muerte) de dos pasajeros ("ocupantes blanco") que se encontraban en el mismo automóvil que colisionó.

\section{Lugar}

Estados Unidos. Base de datos del Fatality Analysis Reporting System, 1988-2000.

\section{Pacientes}

Ocupantes del mismo automóvil mayores de 15 años y apareados según su ubicación en el vehículo, de los cuales al menos uno de ellos fallece. Un total de 61834 pares en asientos delanteros, 5278 pares en asientos traseros y 21127 pares laterales.

\section{Evaluación de los factores de riesgo}

El factor de exposición fue la presencia de otro ocupante con o sin cinturón de seguridad que pudo haber sido arrojado contra el par "blanco". Se establecieron tres bases de datos: una con el par de ocupantes "blanco" en los asientos delanteros, otra con el par de ocupantes "blanco" en los asientos traseros y una tercera, con el par de ocupantes "blanco" del mismo lado del vehículo. El diseño del estudio pretende eliminar variables confundidoras como las características de la colisión (velocidad, lugar y severidad de la colisión, tipo de vehículo, etc.).

\section{Medición de los resultados principales}

Se midió el riesgo relativo de morir a los 30 días de una colisión, ajustando por sexo, edad, posición en el vehículo y uso de cinturón de seguridad.

\section{Resultados Principales}

El riesgo de morir fue mayor para un ocupante de asiento delantero sujeto con cinturón de seguridad ubicado delante de otro ocupante no sujeto, que para un ocupante de asiento delantero sujeto con cinturón de seguridad ubicado delante de otro que sí estaba sujeto (RR ajustado*: 1,20; IC95\%: 1,10 a 1,31). Para un ocupante de asiento trasero sujeto con cinturón ubicado por detrás de un ocupante no sujeto, comparado con uno ubicado por detrás de un ocupante sujeto, el RR ajustado fue 1,22 (IC95\%: 1,10 a 1,36). Para un ocupante sujeto con cinturón ubicado junto a un ocupante no sujeto, comparado con un ocupante sujeto ubicado junto a otro que si estaba sujeto con cinturón, el RR ajustado fue de 1,15 (IC95\%: 1,08 a 1,22). Para los ocupantes no sujetos con cinturón, los $R R$ ajustados fueron, según su situación respecto del otro ocupante no sujeto: 1,04 (IC95\% 0,97 a 1,12) para los ubicados en asiento delantero, 1,22 (IC95\% 1,10 a 1,36), para los situados atrás y 0,85 (IC95\%: 0,80 a 0,92) para los situados al lado.

\section{Conclusiones}

Las personas que quieran reducir el riesgo de morir en una colisión de automóvil deberían usar su propio cinturón de seguridad y pedirle a los demás ocupantes que también lo utilicen.

\section{Comentario}

Numerosos estudios han demostrado hace ya tiempo que el uso del cinturón de seguridad disminuye a la mitad o más el riesgo de morir en una colisión de automóvil. Sin embargo, la asociación entre muerte del ocupante de un vehículo que colisiona y el uso o no uso del cinturón por parte de otros ocupantes del mismo vehículo raramente ha sido explorada ${ }^{2}$.

Los hallazgos de este estudio son consistentes con la hipótesis de que un ocupante no sujeto puede ser catapultado hacia delante, atrás o al costado en caso de colisión aumentando la probabilidad de morir de otros ocupantes, estén éstos sujetos o no. El estudio analiza los resultados con todas las combinaciones posibles desde dos hasta cuatro ocupantes, y de las colisiones desde distintos ángulos. Casi en todos los casos se muestra asociación entre muerte y presencia de otro ocupante no sujeto.

El uso del cinturón de seguridad por el ocupante de un asiento trasero podría evitar una de cada seis muertes de un ocupante de asiento delantero sujeto y el uso del cinturón por un ocupante de asiento trasero haría lo propio con los ocupantes sujetos del asiento trasero.

El riesgo relativo ajustado más bajo se obtuvo cuando todos los ocupantes estaban sujetos. No pudo calcularse el riego absoluto, dado que la mayoría de los sobrevivientes estaban incluidos en la base de datos original.

\section{Conclusiones del comentador}

La recomendación de uso de medidas de seguridad en el tránsito debería ser cotidiana en nuestra práctica ${ }^{3}$. Podemos sumar ahora un fuerte argumento a favor de sugerir que nuestros pacientes no sólo utilicen, sino también hagan utilizar el cinturón de seguridad a todos los ocupantes de los vehículos en que se desplazan.

Guillermo de Hoyos [ Coordinador Programa Prevención y Control del Trauma, Neuquén. ]

De Hoyos G.El uso de cinturón de seguridad también prevendría la muerte de los otros ocupantes del vehículos.Evid. actual. práct. ambul 2004;7:137. Comentado de:Cummings, P, Rivara, F. P. Car Occupant Death According to the Restraint Use of Other Occupants. JAMA, January 21, 2004--Vol 291, No $3,343 / 9$

\section{Referencias}

1.Broughton J. The actual threat posed by unrestrained rear seat car passengers, Accid Anal Prev. 2004 Jul;36(4):627-9

2.Ichikawa M, Nakahara S. Wakai S. Mortality of Front Seat Occupants attributable to unbelted rear seat passengers in car crashes. Lancet 2002, 359 43-44

3.U.S. Preventive Task Force Guide to Clinical Prevention Services, 2nd ed. 1996, Williams \& Wilkins, ,Ch 57 Preventive Motor Vehicle Injuries, 643/57. 